\title{
INTER-RELATIONSHIPS AMONG INTEREST RATES, SAVINGS AND INVESTMENT IN NIGERIA: AN EX POST ANALYSIS FOR 1975-1992 PERIOD WITH PROJECTIONS FOR 2010
}

\author{
${ }^{1}$ OLUBANJO, O. O., ${ }^{1}$ ATOBATELE, J. T. AND ${ }^{2}$ AKINWUMI, J. A. \\ ${ }^{1}$ Department of Agricultural Economics, \\ Olabisi Onabanjo University, Ago-Iwoye, Nigeria \\ Corresponding author's E-mail:oluolay2000@yahoo.com \\ ${ }^{2}$ Department of Agricultural Economics, University of Ibadan, Ibadan, Nigeria.
}

\begin{abstract}
This paper simulated the inter-relationships among interest rates, savings and investment in Nigeria between 1993 and 2010, using historical data on Nigeria spanning a period of 18 years (i.e. 1975-1992). By assuming diverse theoretical underpinnings and approaches, this study examined, in particular, what the connections and the directions of causality imply for interest rates policy, and savings mobilization and investments in Nigeria. Preliminary analysis carried out based on the historical data confirmed that the real interest rates had a negative effect on the investment rate in Nigeria between 1975 and 1992. Also, a positive association was found between the investment rates and the savings rates in Nigeria over the review period. This latter finding, thus suggest that persistent, low or negative real interest rates will discourage or fail to stimulate the savings rates, and may stifle qualitative investment in Nigeria. Ex ante forecasts beyond the historical data period further suggested that a marked decrease in the real lending rate would not result automatically into increased domestic investment. Similarly, a sizeable decline in the real deposit rate will not prevent a marked growth in total savings. Nonetheless, the gross domestic production should posit a 4.2percent growth rate in real terms between 1993 and 2010.
\end{abstract}

Key words: interest rate, investments

\section{INTRODUCTION}

Although questions of interest rates, savings and capital information (investment) have been at the core of economic analysis for two to three centuries, the connections among them and the directions of causality are still far from clear. The traditional view in the literature is that, in developing countries, low income preclude the generation of savings, and hence the mobilization of investment. This view is however challenged by the conventional view that low rates of return to investment (savings) cause low savings, which in turn affect the level of investment. The conventional view, thus implicitly assume that savings (and hence investment) respond positively to increases in rates of return to investments (savings). This 'new' view has implication for development strategies since it tend to suggest that the implementation of a 'realistic' interest rate policy will encourage increased savings and capital formation, and lead to higher growth.

Since the attainment of independence, Nigeria has implemented two interest rates regimes, viz., the low and fixed interest rates regime between 1960 and 1986, and the dynamic interest rates regime since economic deregulation in 1987. Under both interest rates regimes, efforts were geared essentially towards inducing savings for the purpose of channelling it into investment so as to attain higher output and growth. The operation of diverse interest rates (policy) regimes notwithstanding, it is still pertinent to inquire about the inter-relationships among interest rates, savings and investment in Nigeria, and what the connections and the directions of causality imply for interest rates policy, and savings mobilization and investments in Nigeria. Consequently, assuming diverse economic doctrines 
and theoretical approaches, the inter-relationships among interest rates, and aggregate savings and investment rates in Nigeria between 1975 and 1992 are analysed in the paper. Ex post forecasts are thereafter carried out for the period $1993-2010$. The forecasts are based on the results of the ex post simulations conducted using historical data generated for the period $1975-1992$.

\section{METHODOLOGY}

\section{The Data and Analysis}

To facilitate the empirical analysis of the inter-relationships among interest rates, savings and investment in Nigeria, time series data spanning a period of 18 years (i.e. 1975 to 1992) were compiled from published sources including the CBN Statistical Bulletin, and CBN Economic and Financial Reviews. These were analysed using both descriptive and quantitative analytical tools. Specifically, the descriptive analytical tools including tabulations, figures, ratios and percentage analysis were used to analyse interest rates, savings and investment magnitudes in Nigeria. Furthermore, the ordinary least squares (OLS) estimation method was used to fit single-equation (bivariate) econometric models to the study data. The details of the bivariate econometric models fitted to the study data are provided below.

Also, following from Pindyck and Rubinfeld (1981), two simulation time horizons were established, viz., ex post (or historical) simulation period (i.e. 1975 - 1992) and ex ante forecast period (i.e. 1993 - 2010). A set of simultaneous equations was expressed for the purpose of conducting the simulation exercises. Regression parameters were thereafter estimated for the initial period (i.e. 1975 - 1992), and these were used in simulating outcomes for the ex ante forecast period (i.e. 1993 - 2010). Specifically, for the policy simulations, mathematical equations were expressed for the individual endogenous variables. These were fitted to the historical data for the initial period of analysis. Further details about the econometric simulation model analysed in the study are provided below.

\section{The Econometric Models}

\section{(a) Interest Rates vs Aggregate Savings}

In order to determine empirically the relationship between the interest rates and aggregate savings in Nigeria, several bivariate regression equations were expressed and fitted by the OLS estimation method. The implicit forms of the fitted savings functions are provided below.

$$
\begin{aligned}
& G N S_{t}=f\left(N D R_{t}\right) \\
& G N S_{t}=f\left(R D R_{t}\right) \\
& G N S_{t} / C P I_{t}=f\left(R D R_{t}\right) \\
& G N S_{t} / I P D_{t}=f\left(R D R_{t}\right) \\
& G N S_{t} / G D P_{t}=f\left(N D R_{t}\right) \\
& G N S_{t} / G D P_{t}=f\left(R D R_{t}\right)
\end{aligned}
$$


Where,

$G N S_{t}$ is the gross national savings at current prices in year $\mathrm{t}$ in \#' million.

$G N S_{t} / C P I_{t}$ is the real gross national savings at current prices in year $t$ expressed in terms of the consumer price index (CPI) in \#' million;

$G N S_{t} / I P D_{t}$ is the real gross national savings at current prices in year t expressed in terms of the implicit price deflator (IPD) in \#' million;

$G D P_{t}$ is the gross domestic product at current prices in year $\mathrm{t}$ in \#' million;

$N D R_{t}$ is the commercial banks' nominal deposit rate in year $\mathrm{t}$ in percent;

$R D R_{t}$ is the estimated commercial banks' real deposit rate in year $\mathrm{t}$ in percent, estimated algebraically as:

$$
R D R_{t}=\frac{N D R_{t}-I R_{t}}{1+I R_{t}}
$$

$I R_{t}$ is the inflation rate in year $\mathrm{t}$ in percent.

\section{(b) Aggregate Investment Functions}

The implicit forms of the aggregate investment functions estimated by the OLS estimation method in this study are provided below.

$$
\begin{aligned}
& G F C F_{t}=f\left(N L R_{t}\right) \\
& G F C F_{t}=f\left(R L R_{t}\right) \\
& G F C F_{t}=f\left(N D R_{t}\right) \\
& G F C F_{t} / C P I_{t}=f\left(R D R_{t}\right) \\
& G F C F_{t} / I P D_{t}=f\left(N D R_{t}\right) \\
& G F C F_{t} / I P D_{t}=f\left(R D R_{t}\right) \\
& G F C F_{t} / G D P_{t}=f\left(R D R_{t}\right) \\
& G F C F_{t} / G D P_{t}=f\left(N L R_{t}\right) \\
& G F C F_{t} / G D P_{t}=f\left(R L R_{t}\right) \\
& \Delta G D P_{l t} / G F C F_{t}=f\left(N D R_{t}\right) \quad \ldots . . . \\
& \Delta G D P_{l t} / G F C F_{t}=f\left(R D R_{t}\right) \\
& G F C F_{t} / G D P_{l t}=f\left(G N S_{t} / G D P_{t}\right.
\end{aligned}
$$

Where,

$G D P_{t}$ is the nominal gross domestic product at current prices in year $\mathrm{t}$ in \#' million;

$\triangle G D P_{t}$ is the growth in the nominal gross domestic product in year $\mathrm{t}$ in \#' million;

$G F C F_{t}$ is the nominal gross fixed capital formation in year $\mathrm{t}$, in \#' million employed as a proxy for the gross domestic investment:

$G F C F_{t} / C P I_{t}$ is the real gross fixed capital formation in year $t$ expressed in terms of the CPI in \#' million;

$G F C F_{t} / I P D_{t}$ is the real gross fixed capital formation in year t expressed in terms of the IPD 
in \#' million;

$N L R_{t}$ is the commercial banks' nominal prime lending rate in year $\mathrm{t}$ in percent;

$N L R_{t}$ is the estimated commercial banks' real prime lending rate in year $\mathrm{t}$ in percent. It is given algebraically as,

$$
R L R_{t}=\frac{N L R_{t}-I R_{t}}{1+I R_{t}}
$$

\section{The Simulation Model}

For the purpose of simulating the aggregate savings-investment behaviour in Nigeria between 1975 and 1992, and with projections for 2010, a simple, small-sized, open economy, multi-equation econometric model that does not allow for capital transfer was employed as the simulation model. Specifically, the model has the following components:

(i) The savings function:

$$
G N S_{t}=f\left(G D P_{t}, N D R_{t-1}, I R_{t}\right)
$$

(ii) The consumption function:

$$
G C E_{t}=f\left(G D P_{t}, G C E_{t-1}, B M S_{T}-B M S_{T-1}, I R_{T}\right)
$$

(iii) The investment function:

$$
G F C F_{t}=f\left(G D P_{t-1}, G D P_{t}-G D P_{t-1}, N L R_{t}, G N S_{t}-G N S_{t-1}, I R_{t}\right)
$$

(iv) The interest rates functions:

$$
\begin{array}{r}
N D R_{t}=f\left(G D P_{t}, G D P_{t}-G D P_{t-1}, N M S_{t}-N M S_{t-1}, N D R_{t-1}+N D R_{t-2}, I R_{t}\right) \ldots \ldots \ldots \\
N D R_{t}=f\left(G D P_{t}, G D P_{t}-G D P_{t-1}, N M S_{t}-N M S_{t-1}, N L R_{t-1}+N L R_{t-2}, I R_{t}\right)
\end{array}
$$

(v) The national income identity:

$$
G D P_{t}=G C E_{t}+G F C F_{t}+E X P_{t}-I M P_{t}
$$

Where,

$G N S_{t-1}$ is the nominal gross national savings in the previous period in \#' million;

$G C E_{t}$ and $G C E_{t-1}$ are the nominal gross (i.e. government plus private) consumption expenditures in the current and previous periods in \#' million;

$R D R_{t-1}$ and $R D R_{t-2}$ are the commercial banks' nominal deposit rates in the previous periods in percent;

$R L R_{t-1}$ and $R L R_{t-2}$ are the commercial banks' nominal prime lending rates in the previous periods in percent;

$G N S_{t}-G N S_{t-1}$ is the change in the nominal gross national savings between the current and previous periods in \#' million;

$N M S_{t}-N M S_{t-1}$ is the change in the nominal broad money supply between the current and privatelyprevious periods in \#' million; where NMS is the currency outside bank plus held demand deposits with commercial banks and the Central Bank.

$B M S_{t}-B M S_{t-1}$ is the change in the nominal broad money supply between the current and previous periods in \#' million; where BMS is the NMS plus the savings and time deposits with commercial banks plus total deposit liabilities of the merchant banks (i.e. quasimoney). 
EXPt is the nominal value of total exports in the current period in \#' million; and $I M P_{t}$ is the nominal value of total exports in the current period in \#' million.

The system of equations (i.e. EQ.21 to EQ.26) was estimated using the two stage least squares (2SLS) estimation procedure. Specifically, the method was used to instrumentalise GDP in the current period, using as instruments the first lags of GDP, GCE and NLR, changes in BMS and GNS between the current and previous periods, inflation rate, and import and export magnitudes in the current period. Evaluation of the predictive performance of the individual equations in the model was done using several simulation error statistics including root mean square simulation error (rms error), root mean square percent error (rms $\%$ error), mean simulation error (mean error), mean percent simulation error (mean \% error), root mean square error (actual and simulated), Theil's inequality coefficient (U), and root mean square error (forecast).

\section{EMPIRICAL FINDINGS}

\section{Interest Response of Savings and Investment in Nigeria: 1975 - 1992}

Table 1 presents time series on savings and investment ratios, and interest and inflation rates in Nigeria between 1975 and 1992. Statistics showed that the savings ratio was generally high between 1975 and 1980 (i.e. an era characterised by declining inflation rates, and rising real deposit rates). Savings ratios, however, dropped from 0.22 in 1980 to 0.03 in 1987 (i.e. the year immediately following the period of interest rates deregulation in Nigeria). In particular, the period 1981 to 1987 was characterised by widely undulating inflation rates with bouts of medium level inflation of between 21percent (in 1981) and 40percent (in 1984). With deregulation, however, the interest rates on deposits improved, thereby constituting incentives for encouraging higher savings ratios, especially between 1988 and 1992. The savings ratio was about 0.21 , on the average, in the periods following interest rates deregulation in the financial sector. The ratios were even at the peak values (i.e. 0.27 and 0.28, respectively) in 1989 and 1990. Nonetheless, the average savings ratio for Nigeria between 1975 and 1992 was 0.15 .

The annual investment ratios for the country were generally above the mean (i.e. 0.17) in periods before 1983 (Table 1). Moreover, between 1975 and 1982, aggregate investment generally formed at least 20percent of the GDP in Nigeria. Beyond 1982, however, the investment ratios were generally below the mean value for the entire eighteen-year period. This was probably due to the high and widely oscillating inflationary level, and the growing lending rates especially in the wake of the interest rates deregulation. The ratios actually oscillated within a narrow band of 0.08 and 0.14 between 1983 and 1992. Consequently, the savings-investment gap ratios were generally higher in the post-deregulation period. This signified that the bulk of the domestic savings was consumed or used in capital flight as opposed to being channelled into qualitative investments.

\section{Interest Rates - Savings Relations}

The results of the bivariate analysis of the impact of the interest rates on total savings in Nigeria between 1975 and 1992 are provided in Table 2. In accordance with the theoretical expectations, empirical results revealed that the nominal deposit rate significantly and positively influenced the gross national savings (EQ.1). The r-squared value was 0.51 . The real deposit rate also had a positive impact on the gross national savings; although, this was found to be insignificant at any of the chosen test levels (EQ.2). The r-squared value obtained for the relationship was in fact barely above zero (i.e. 0.03 ). 
${ }^{\text {a,b,c }}$ Estimated regression parameters significant at the 1percent, 5percent and 10percent levels, respectively. $\mathrm{r}^{2}$ is the $\mathrm{R}$-squared value for the fitted equation. $\mathrm{F}$ is the $\mathrm{F}$-value for the fitted equation. $\mathrm{N}$ is the span of the time series data used in the study. Other variables are as defined in the paper.

However, when total savings level in Nigeria was expressed in real terms (that is, as a ratio of either the consumer price index, CPI or the implicit price deflator, IPD), the coefficient on the real deposit rate was negative and non-significant even at 10percent level (EQ.3 and EQ.4). Also, as for EQ.2, the r-squared values were barely above zero for the two equations, thus confirming the poor association between the real gross national savings and real deposit rates in Nigeria during the review period. 
Journal of Agriculture and Social Research (JASR) VOL. 10, No. 1, 2010

Table 1: Interest Rates, and Aggregate Savings and Investment in Nigeria, 1975 to 1992

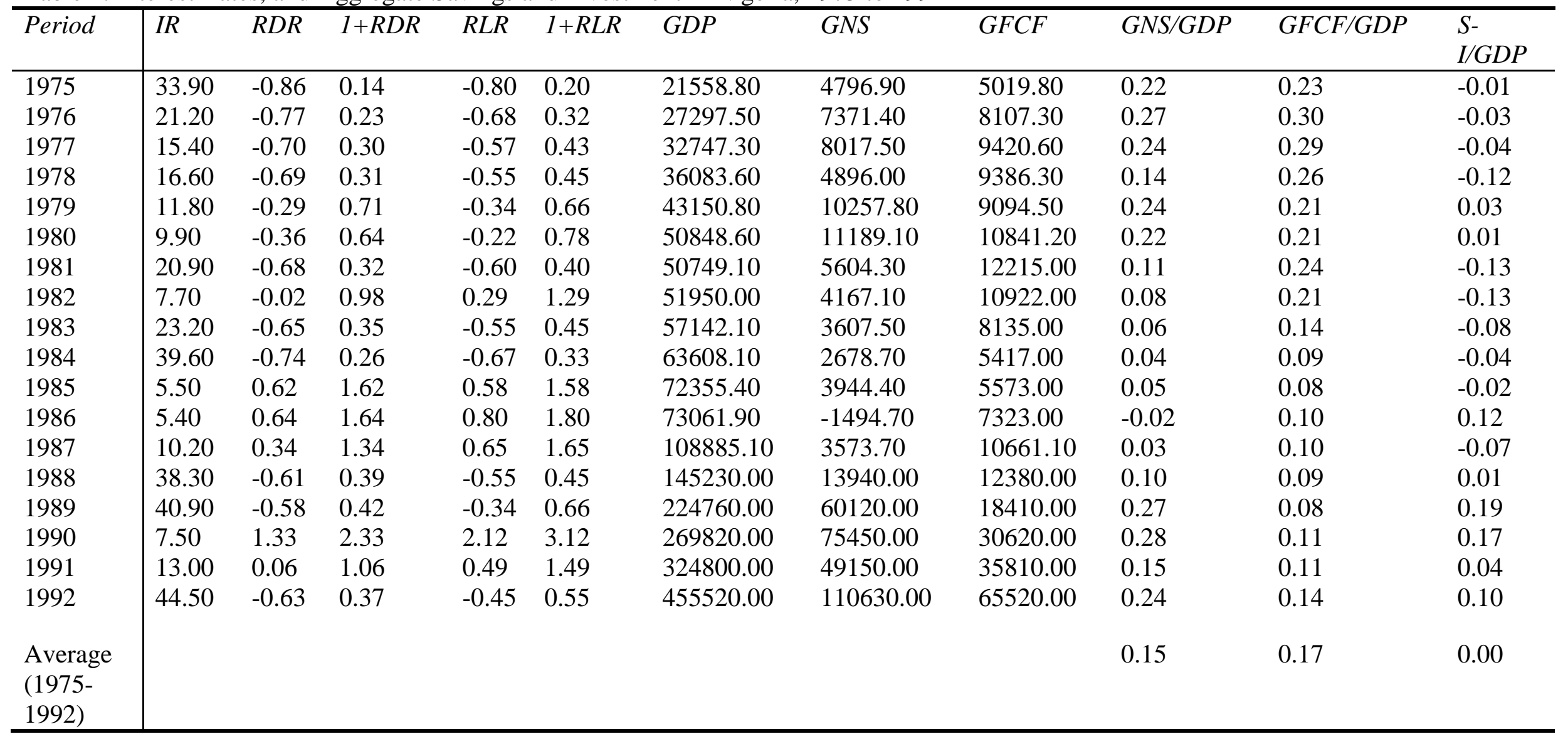

Notes: S-I is the Gross National Savings (GNS) minus the Gross Fixed Capital Formation (GFCF) in A'million.

Other variables are as defined in the methodology section.

Source: CBN (1992) and Computations Based on CBN data. 
Table 2: Estimated Linear Interest Rates- Savings Relations for Nigeria: 1975-1992

\begin{tabular}{|c|c|c|c|c|}
\hline Equation No. & Regression Equation & $r^{2}$ & $F$ & $\bar{N}$ \\
\hline EQ. 1: & $\begin{array}{c}\text { GNS }=-2253422+4599.18 \\
\text { NDR } \\
(-1.08)^{\mathrm{c}} \quad(4.12)^{\mathrm{a}}\end{array}$ & 0.51 & 16.94 & 18 \\
\hline EQ.2: & $\mathrm{GNS}=23142.53+8423.94 \mathrm{RDR}$ & 0.03 & 0.46 & 18 \\
\hline EQ.3: & $\begin{array}{c}\text { GNS }=138.74-34.62 \text { RDR } \\
(5.11)^{\mathrm{a}}(-0.82)\end{array}$ & 0.04 & 0.67 & 18 \\
\hline EQ.4: & $\begin{aligned} \text { GNS }= & 125.20-26.82 \text { RDR } \\
& (4.92)^{\mathrm{a}} \quad(-0.68)\end{aligned}$ & 0.03 & 0.46 & 18 \\
\hline EQ.5: & $\begin{array}{l}\text { GNS/GDP }=0.15+3.25 \mathrm{E}-04 \\
\mathrm{NDR}\end{array}$ & 0.00 & 0.00 & 18 \\
\hline EQ.6: & $\begin{aligned} &(2.80)^{\mathrm{b}}(0.07) \\
& \text { GNS/GDP }= 0.14-0.03 \text { RDR } \\
&(5.66)^{\mathrm{a}}(-0.78) \\
&\end{aligned}$ & 0.05 & 0.77 & 18 \\
\hline
\end{tabular}

Notes: Figures in parentheses are t-statistics for the estimated regression parameters.

Furthermore, when the gross national savings was expressed as a ratio of the gross domestic product, the nominal deposit rate indicated a positive impact, (EQ.5) while the real deposit rate showed a negative impact (EQ.6 and Figure 1). Both nominal and real deposit rates, however, indicated no significant impact on the savings ratio in Nigeria between 1975 and 1992. Nonetheless, the nominal interest elasticity of savings for Nigeria was 2.07 while the real interest elasticity of savings for the country during the period under review was 0.01 .

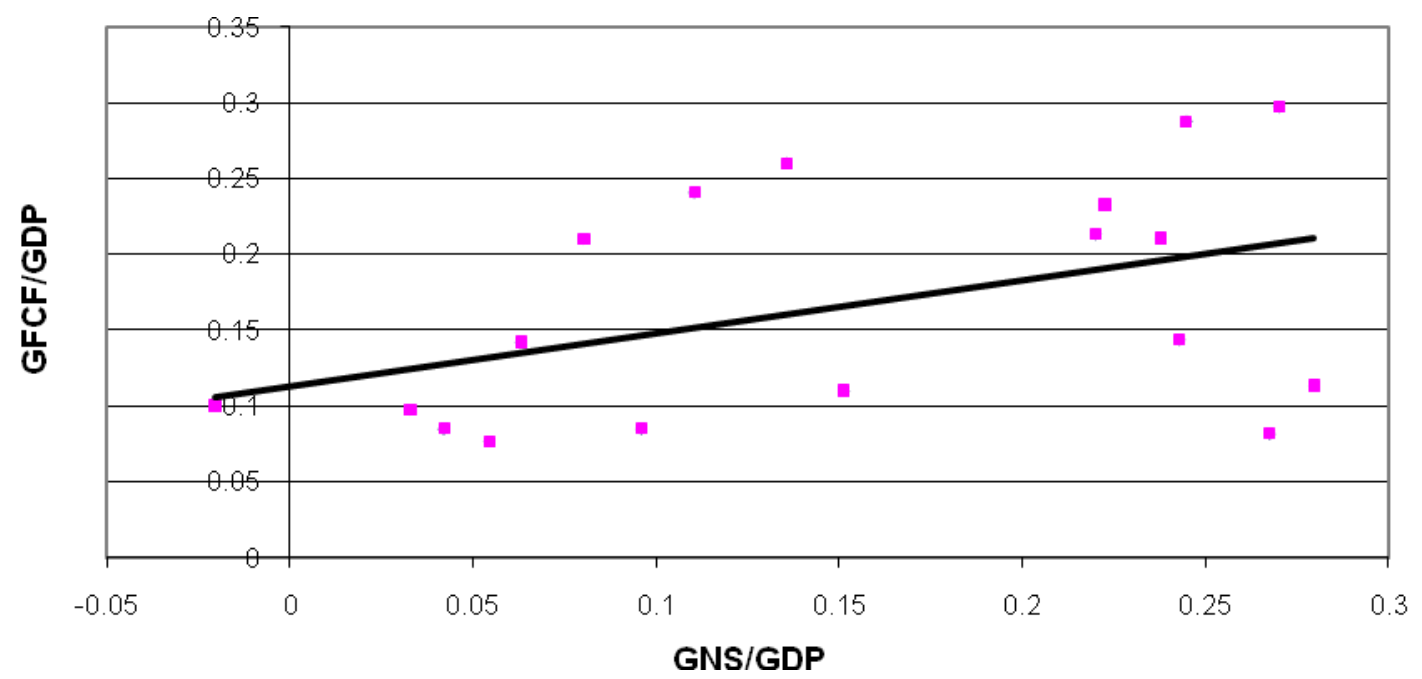

Figure 1: Aggregate Investment Ratios vs Total Savings Ratios in Nigeria, 1975 to 1992.

\section{Investment Relations and Savings-Investment Correlation for Nigeria}

Table 3 provides the results of the empirical estimations of the relevant bivariate investment functions for Nigeria, using time series data for the period 1975-92. Contrary to theoretical expectations, empirical result (EQ.7) showed that the nominal lending rate had a positive and significant effect on the gross fixed capital formation (that is, a proxy for gross domestic investment). The r-squared value was 0.49 . The impact was however found to be non-significant for the real lending rate at the 10 percent level (EQ.8). 
In line with the theoretical expectations, both the nominal and real deposit rates indicated significant and negative impact on real gross domestic investment in Nigeria between 1975 and 1992 (EQ.9, EQ.10 and EQ.12; see also Figure 2). Further, in accordance with a priori expectations, both the real and nominal lending rates showed a negative and significant effect on investment ratio (EQ.14 and EQ.15). The real deposit rate also indicated a significant, negative effect on investment ratio in Nigeria (EQ.13). As such, a 1 percent rise, in either the real deposit or lending rates will lower investment ratio by 0.06 percent or 0.05 percent, respectively (EQ.13 and EQ.15).

Table 3: Estimated Linear Investment Function for Nigeria: 1975-1992

\begin{tabular}{|c|c|c|c|c|}
\hline Equation No. & Regression Equation & $r^{2}$ & $F$ & $N$ \\
\hline EQ.7: & $\begin{array}{c}\text { GFCF }=-3679.02+1480.25 \text { NLR } \\
(3.91)^{\mathrm{a}} \quad(-0.67)\end{array}$ & 0.49 & 15.25 & 18 \\
\hline EQ.8: & $\begin{array}{l}\mathrm{GFCF}=15581+4041.81 \mathrm{RLR} \\
(0.83) \\
(4.34)^{\mathrm{a}}\end{array}$ & 0.04 & 0.69 & 18 \\
\hline EQ.9: & $\frac{\mathrm{GFCF}}{\mathrm{CPI}}=\frac{199.19-3.30 \mathrm{E}-04 \mathrm{NDR}}{(6.57)^{\mathrm{a}} \quad(-1.86)^{\mathrm{c}}}$ & 0.19 & 3.46 & 18 \\
\hline EQ.10: & $\frac{\mathrm{GFCF}}{\mathrm{CPI}}=\begin{array}{c}144.73-67.92 \mathrm{RDR} \\
(6.38)^{\mathrm{a}} \quad(-1.93)^{\mathrm{c}}\end{array}$ & 0.20 & 3.70 & 18 \\
\hline EQ.11: & $\frac{\mathrm{GFCF}}{\operatorname{IPD}}=\underset{(6.35)^{\mathrm{a}}}{165.52-2.27 \mathrm{E}-04 \mathrm{NDR}}$ & 0.13 & 2.22 & 18 \\
\hline EQ.12: & $\frac{\mathrm{GFCF}}{\mathrm{IPD}}=\underset{(6.68)^{\mathrm{a}}}{125.72-55.37 \mathrm{RDR}}(-1.89)^{\mathrm{c}}$ & 0.19 & 3.57 & 18 \\
\hline EQ.13: & 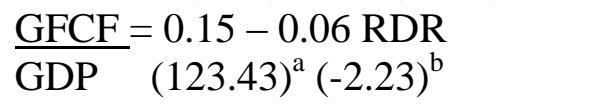 & 0.24 & 4.74 & 18 \\
\hline EQ.14: & $\begin{array}{l}\underline{\mathrm{GFCF}}=0.26-0.01 \mathrm{NLR} \\
\mathrm{GDP} \\
(9.08)^{\mathrm{a}}(-3.57)^{\mathrm{a}}\end{array}$ & 0.47 & 14.03 & 18 \\
\hline EQ.15: & 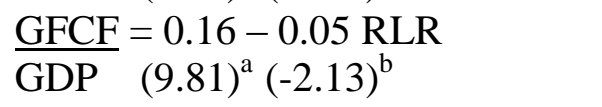 & 0.22 & 4.54 & 18 \\
\hline EQ.16: & $\begin{array}{l}\frac{\mathrm{DGDP}}{\mathrm{GFCF}}=-0.51+0.19 \mathrm{NDR} \\
(-1.06)(4.02)^{\mathrm{a}}\end{array}$ & 0.54 & 17.64 & 17 \\
\hline EQ.17: & $\underline{\Delta} \underline{\mathrm{GDP}}=1.34+0.09 \mathrm{RDR}$ & 0.00 & 0.03 & 17 \\
\hline EQ.18: & $\begin{array}{l}\overline{\text { GFCF }} \quad(4.08)^{\mathrm{a}} \quad(0.19) \\
\overline{\text { GFCF }}=0.12+0.33 \text { GNS/GDP } \\
\overline{\text { GDP }}(50.35)^{\mathrm{a}}(1.87)^{\mathrm{a}}\end{array}$ & 0.42 & 3.50 & 18 \\
\hline
\end{tabular}

Note: See the footnotes in Table 2 and the methodology for the descriptions of the fitted variables and other diagnostic statistics. 


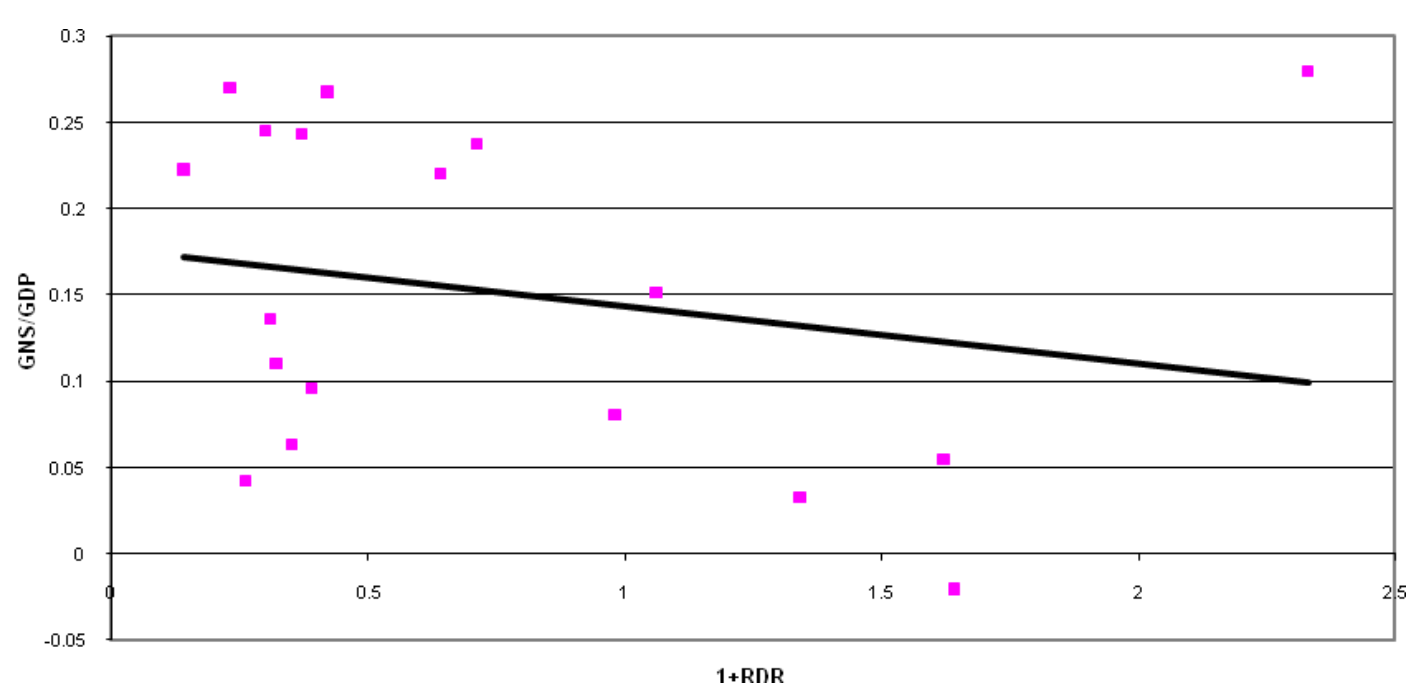

Figure 2: Total Savings Ratio vs Real Interest Rates in Nigeria, 1975 to 1992.

The nominal interest elasticity of investment in Nigeria during the review period was 0.87, while the real interest elasticity of investment during the same period was 0.01 . Furthermore, ignoring the spread between the prevailing deposit and lending rates in the financial sector in Nigeria, Table 3 (EQ.16) indicated that a rise in the nominal deposit rate will improve investment efficiency, proxied by the incremental output-capital ratio $($ i.e $\triangle G D P / G F C F)$. In particular, a 1 percent increase in the nominal deposit rate will raise investment efficiency by about 0.2 percent.

To determine the saving-investment correlation for Nigeria, this study further fitted the Feldstein-Horioka regression (that is, equation 19 above) to relevant aggregate data for the period 1975-92. According to the empirical result in Table 3 (EQ.18), long term aggregate savings and domestic investment ratios in Nigeria showed a significant, positive association. This empirical finding is in agreement with the finding in previous studies (e.g. Feldstein and Horioka, 1980; Dooley, Frankel and Mathieson, 1987). Moreover, the savingsinvestment correlation, $\mathrm{r}$, for Nigeria was found to be about 0.65 ; thus indicating (as obvious too in Figure 3) that the higher the savings ratio, the higher would be the investment ratio within the country. Tests of the significance of the difference of the regression coefficient from zero and unity further confirmed that the nation's economy between 1975 and 1992 was neither wholly open nor closed in nature. Moreover, a comparison of the estimated regression coefficient for Nigeria (i.e. 0.33) with a benchmark value (that is, the small industrial country value of 0.6 derived by Murphy, 1984), confirmed that there was high capital mobility in Nigeria during the period reviewed. This finding tends to suggest, in addition, that domestic investment in Nigeria during the review period was not financed wholly with national savings. Specifically, the high capital mobility implied that savings in Nigeria ideally has the potential of flowing to whatever part of the world offers the highest rate of return. As such, any increase in national savings is likely to show primarily in a lower current account deficit as opposed to a higher domestic investment. 


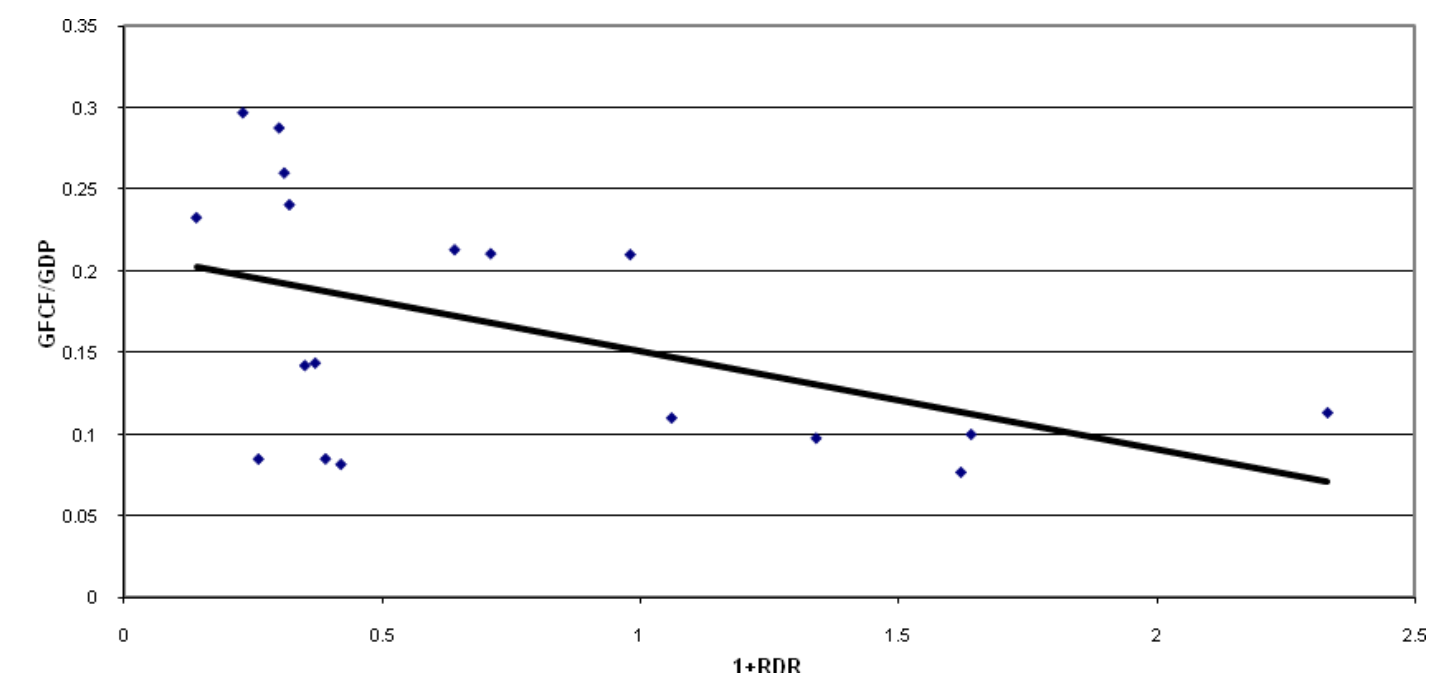

Figure 3: Aggregate Investment Ratios vs Real Interest Rates in Nigeria 1975-1992.

\section{Relationships among Real Interest Rates, Savings and Investment Rates in Nigeria}

In this study, an attempt was also made to establish a linkage between the real interest rates and investment, through savings. In particular, the question was asked whether a persistent, low or negative real interest rates in Nigeria will encourage higher saving rates, and hence, higher investment rates. Although the nominal deposit rate indicated a significant, positive impact on total savings (Table 2; EQ.1), further analysis for Nigeria suggested a negative but non-significant correlation between saving rates and the real interest rates (Table 2, EQ.6). A significant, negative association was however observed between investment rates and the real interest rates (Table 3; EQ.13; EQ.15). These findings, coupled with an earlier finding confirming a positive and significant association between the investment rates and the savings rates (Table 3; EQ.18), tend to suggest that persistent, low or negative real interest rates will discourage (or fail to stimulate) saving rates, and hence stifle qualitative investment in Nigeria.

\section{Results of the Simulation Analysis}

The results of the 2SLS estimation of the system of equations (i.e. EQ.21 to EQ.26 above) are presented in Table 4 . The $\mathrm{R}^{2}$ values for the individual equations ranged between 0.78 and 0.99 . Table 5 further presents the simulation error statistics in respect of the ex post simulations and ex ante forecasts of GNS, GCE, GFCF, GDP, NDR, and NLR in Nigeria between 1975 and $1992^{1}$. Suffice to add that empirical evidence from the historical simulations tends to suggest adequate reproduction of the general long-run behaviour of the actual series by the simulated series. Specifically, the rms \% errors were generally less than 1.5 percent. The mean \% errors and the Theil's inequality coefficients were not more than 0.12 percent. Furthermore, rms (actual) and rms (simulated) were approximately of similar magnitudes. The fitted equations in Table 4 should thus be useful in conducting policy simulation exercises beyond the historical period analysed in the study. As such, the ex ante forecasts of the key policy variables examined in this study are presented (and discussed) below.

\footnotetext{
${ }^{1}$ Details including actual and simulated time series, and pictorial forms in respect of the historical simulations of GNS, GCE, GFCF, GDP, NDR, and NLR in Nigeria between 1975 and 1992 can be found in Olubanjo (2001).
} 


\section{Ex Ante Forecasts}

Table 6 presents the results of the ex ante forecasts of GNS, GCE, GFCF, GDP, NDR, and NLR in Nigeria between 1993 and 2010. In the forecasts, it was implicitly assumed that the growth rates for the individual macro variables beyond 1992 would be equal to the average annual (or historical) growth rates experienced between 1975 and 1992. Results indicated that real GNS will experience 9.32percent growth; that is, a rise in nominal terms from \#65843.43million in 1993 to \#151205.96million in 2010. Real GCE will, however, experience an increase, although by a much reduced magnitude (i.e. 5.05percent) over the forecast period. It will increase nominally from $\# 254085.57 \mathrm{million}$ in 1993 to \#560750.76million in 2010. 
Table 4: Results of the Two-Stage Least Squares Estimation of the Simultaneous Equations Model

\begin{tabular}{|c|c|c|c|c|c|}
\hline $\begin{array}{l}\text { Equ } \\
\text { atio } \\
n \\
\text { No. }\end{array}$ & Regression Function & $R^{2}$ & $\begin{array}{l}F- \\
\text { Stat }\end{array}$ & $D W$ & $N$ \\
\hline $\begin{array}{l}\text { EQ. } \\
19:\end{array}$ & $\begin{array}{l}\mathrm{GNS}_{\mathrm{t}}=1333.4319+0.3077 \mathrm{GDP}_{\mathrm{t}}^{*}-1980.7726 \mathrm{NDR}_{\mathrm{t}-1}+ \\
\begin{array}{c}42.5482 \mathrm{IR}_{\mathrm{t}} \\
\quad(0.182)\end{array} \\
(0.199)\end{array}$ & 0.92 & 47.16 & $1.50^{\mathrm{d}}$ & 18 \\
\hline $\begin{array}{l}\text { EQ. } \\
20:\end{array}$ & $\begin{array}{l}\mathrm{GCE}_{\mathrm{t}}=-10362.1845+0.4270 \mathrm{GDP}_{\mathrm{t}}^{*}+0.3226 \mathrm{GCE}_{\mathrm{t}-1}+ \\
\begin{array}{c}3.0696 \mathrm{BMS}_{\mathrm{t}}-\mathrm{BMS}_{\mathrm{t}-1}+549.9333 \mathrm{IR}_{\mathrm{t}} \\
(-0.786)\end{array} \\
(2.542)^{\mathrm{b}}\end{array}$ & 0.98 & $\begin{array}{l}120.2 \\
2\end{array}$ & $1.60^{\mathrm{d}}$ & 18 \\
\hline $\begin{array}{l}\text { EQ. } \\
21:\end{array}$ & $\begin{array}{l}\mathrm{GFCF}_{\mathrm{t}}=9342.149+0.2741 \mathrm{GDP}_{\mathrm{t}-1}-0.0846 \mathrm{GDP}_{\mathrm{t}}-\mathrm{GDP}_{\mathrm{t}-1}- \\
\begin{array}{c}1516.3808 \mathrm{NLR}_{\mathrm{t}-1} \\
(3.941)^{\mathrm{a}}\end{array} \underbrace{\mathrm{a}}\left(7.1279 \mathrm{GNS}_{\mathrm{t}}-\mathrm{GNS}_{\mathrm{t}-1}-18.7658 \mathrm{IR}_{\mathrm{t}}\right. \\
(-5.244)^{\mathrm{a}}\end{array}$ & 0.97 & 72.95 & $1.83^{\mathrm{d}}$ & 18 \\
\hline $\begin{array}{l}\text { EQ. } \\
22:\end{array}$ & $\begin{array}{l}\mathrm{NDR}_{\mathrm{t}}=6.0100+1.6004 \mathrm{E}-05 \mathrm{GDP}_{\mathrm{t}}^{*}+1.0184 \mathrm{E}-04 \mathrm{GDP}_{\mathrm{t}}{ }^{-} \\
\mathrm{GDP}_{\mathrm{t}-1}+0.9900 \mathrm{NDR}_{\mathrm{t}-1}+\mathrm{NDR}_{\mathrm{t}-2}-1.16111 \mathrm{E}-04 \mathrm{NMS}_{\mathrm{t}}-\mathrm{NMS}_{\mathrm{t}-1} \\
-0.0313 \mathrm{IR}_{\mathrm{t}} \\
\quad(3.479)^{\mathrm{a}} \quad(0.719) \\
(2.147)^{\mathrm{c}} \\
0.448)\end{array}$ & 0.78 & 6.97 & $1.80^{\mathrm{d}}$ & 18 \\
\hline $\begin{array}{l}\text { EQ. } \\
\text { 23: }\end{array}$ & 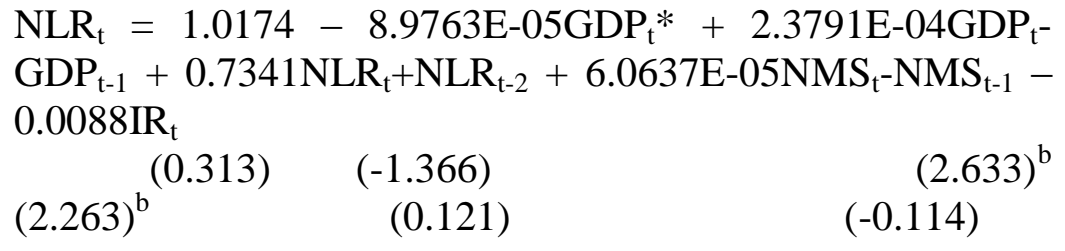 & 0.88 & 13.95 & $2.17^{\mathrm{d}}$ & 18 \\
\hline $\begin{array}{l}\text { EQ. } \\
24:\end{array}$ & 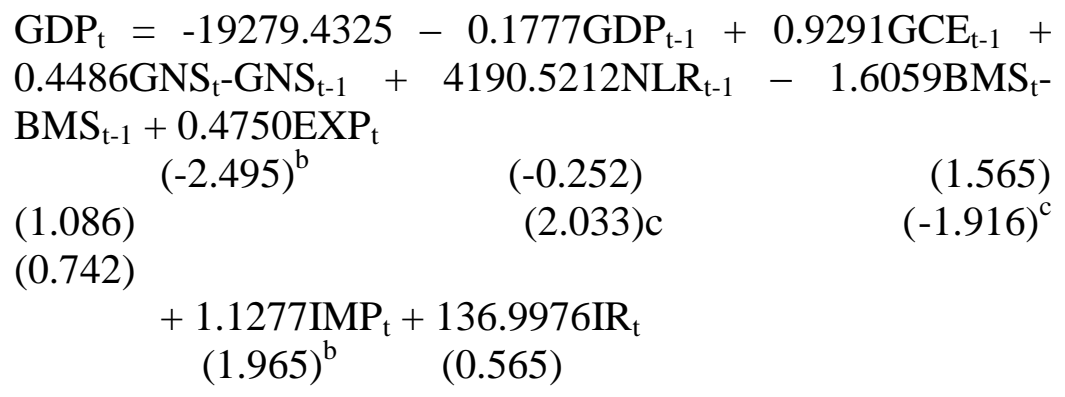 & 0.99 & $\begin{array}{l}496.5 \\
8\end{array}$ & $1.23^{\mathrm{d}}$ & 18 \\
\hline
\end{tabular}

Notes: See footnotes in Table 2 and the methodology for details about the fitted variables and the diagnostic statistics. ${ }^{\mathrm{d}} \mathrm{DW}-$ Durbin Watson statistics significant at the 10percent level. 
Journal of Agriculture and Social Research (JASR) VOL. 10, No. 1, 2010

Table 5: Results of Ex Post (Historical) and Ex Ante (Forecast) Simulations - Model Evaluation.

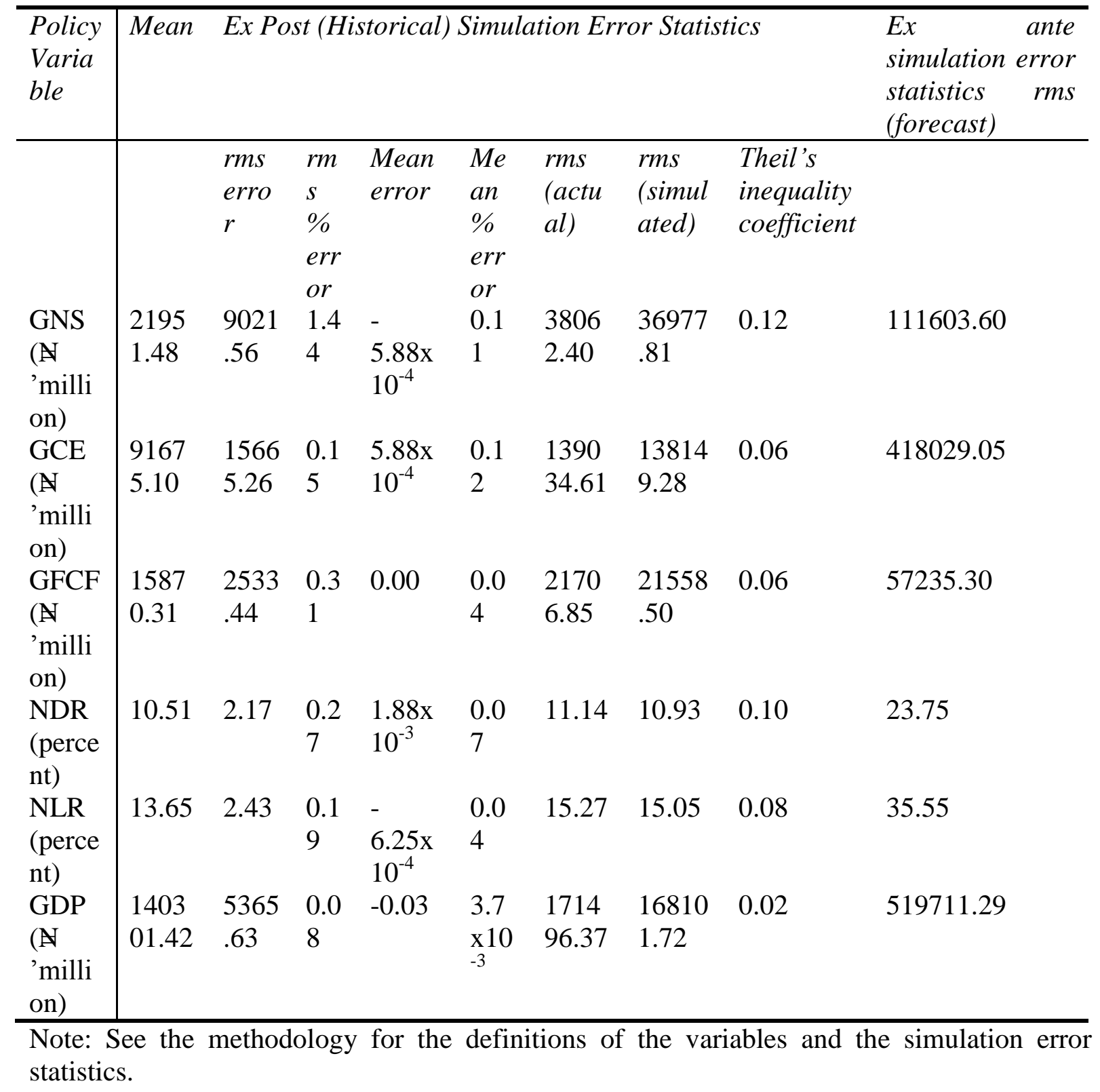


Table 6: Results of Ex Ante Forecasts of the Nominal Gross National Savings, Gross Consumption Expenditures, Gross Fixed

Capital Formation, Gross Domestic Products (N'million), and Savings and Prime Lending Rates (percent) in Nigeria, 1993 to

2010.

\begin{tabular}{|c|c|c|c|c|c|c|c|c|c|c|c|c|c|}
\hline $\begin{array}{l}\mathrm{Pe} \\
\text { rio } \\
d\end{array}$ & $\begin{array}{l}\text { Implicit } \\
\text { Price } \\
\text { Deflator }\end{array}$ & GNS & & $G C E$ & & $G F C F$ & & $\overline{N D R}$ & & $N L R$ & & $\overline{G D P}$ & \\
\hline & & $\begin{array}{l}\text { Nom } \\
\text { inal }\end{array}$ & $\begin{array}{l}\mathrm{Re} \\
\mathrm{al}\end{array}$ & $\begin{array}{l}\text { Nom } \\
\text { inal }\end{array}$ & $\begin{array}{l}\mathrm{Re} \\
\mathrm{al}\end{array}$ & $\begin{array}{l}\text { Nom } \\
\text { inal }\end{array}$ & $\begin{array}{l}\mathrm{Re} \\
\mathrm{al}\end{array}$ & $\begin{array}{l}\text { No } \\
\text { min } \\
\text { al }\end{array}$ & $\begin{array}{l}\mathrm{R} \\
\mathrm{e} \\
\mathrm{a} \\
\mathrm{l}\end{array}$ & $\begin{array}{l}\text { No } \\
\text { min } \\
\text { al }\end{array}$ & $\begin{array}{l}\mathrm{Re} \\
\text { al }\end{array}$ & $\begin{array}{l}\text { Nom } \\
\text { inal }\end{array}$ & $\begin{array}{l}\mathrm{Re} \\
\mathrm{al}\end{array}$ \\
\hline 19 & 342.27 & 6584 & 19 & 2540 & 74 & 3623 & 10 & 16. & 0 & 24. & 0. & 3177 & 92 \\
\hline 93 & & 3.43 & $\begin{array}{l}2.3 \\
7\end{array}$ & $\begin{array}{l}85.5 \\
7\end{array}$ & $\begin{array}{l}2.3 \\
5\end{array}$ & 0.77 & $\begin{array}{l}5 . \\
85\end{array}$ & 77 & $\begin{array}{l}. \\
0 \\
5\end{array}$ & 31 & 07 & $\begin{array}{l}89.2 \\
3\end{array}$ & $\begin{array}{l}8.4 \\
8\end{array}$ \\
\hline $\begin{array}{l}19 \\
94\end{array}$ & 364.43 & $\begin{array}{l}7086 \\
3.89\end{array}$ & $\begin{array}{l}19 \\
4.4 \\
5\end{array}$ & $\begin{array}{l}2721 \\
28.5 \\
5\end{array}$ & $\begin{array}{l}74 \\
6.7 \\
2\end{array}$ & $\begin{array}{l}3855 \\
1.24\end{array}$ & $\begin{array}{l}10 \\
5 . \\
79\end{array}$ & $\begin{array}{l}17 . \\
56\end{array}$ & $\begin{array}{l}0 \\
0 \\
0 \\
5\end{array}$ & $\begin{array}{l}25 . \\
56\end{array}$ & $\begin{array}{l}0 . \\
07\end{array}$ & $\begin{array}{l}3400 \\
20.7 \\
6\end{array}$ & $\begin{array}{l}93 \\
3.0 \\
2\end{array}$ \\
\hline $\begin{array}{l}19 \\
95\end{array}$ & 386.60 & $\begin{array}{l}7588 \\
3.93\end{array}$ & $\begin{array}{l}19 \\
6.2 \\
9\end{array}$ & $\begin{array}{l}2901 \\
66.0 \\
7\end{array}$ & $\begin{array}{l}75 \\
0.5 \\
6\end{array}$ & $\begin{array}{l}4087 \\
1.89\end{array}$ & $\begin{array}{l}10 \\
5 . \\
72\end{array}$ & $\begin{array}{l}18 . \\
34\end{array}$ & $\begin{array}{l}0 \\
0 \\
0 \\
5\end{array}$ & $\begin{array}{l}26 . \\
81\end{array}$ & $\begin{array}{l}0 . \\
07\end{array}$ & $\begin{array}{l}3622 \\
50.9 \\
2\end{array}$ & $\begin{array}{l}93 \\
7.0 \\
2\end{array}$ \\
\hline $\begin{array}{l}19 \\
96\end{array}$ & 408.76 & $\begin{array}{l}8090 \\
3.96\end{array}$ & $\begin{array}{l}19 \\
7.9 \\
3\end{array}$ & $\begin{array}{l}3082 \\
03.5 \\
9\end{array}$ & $\begin{array}{l}75 \\
4.0 \\
0\end{array}$ & $\begin{array}{l}4319 \\
2.54\end{array}$ & $\begin{array}{l}10 \\
5 . \\
67\end{array}$ & $\begin{array}{l}19 . \\
12\end{array}$ & $\begin{array}{l}0 \\
0 \\
0 \\
5\end{array}$ & $\begin{array}{l}28 . \\
06\end{array}$ & $\begin{array}{l}0 . \\
07\end{array}$ & $\begin{array}{l}3844 \\
81.0 \\
6\end{array}$ & $\begin{array}{l}94 \\
0.6 \\
0\end{array}$ \\
\hline $\begin{array}{l}19 \\
97\end{array}$ & 430.92 & $\begin{array}{l}8592 \\
4.00\end{array}$ & $\begin{array}{l}19 \\
9.4 \\
0\end{array}$ & $\begin{array}{l}3262 \\
41.1 \\
1\end{array}$ & $\begin{array}{l}75 \\
7.0 \\
8\end{array}$ & $\begin{array}{l}4551 \\
3.19\end{array}$ & $\begin{array}{l}10 \\
5 . \\
62\end{array}$ & $\begin{array}{l}19 . \\
89\end{array}$ & $\begin{array}{l}0 \\
. \\
0 \\
5\end{array}$ & $\begin{array}{l}29 . \\
31\end{array}$ & $\begin{array}{l}0 . \\
07\end{array}$ & $\begin{array}{l}4067 \\
11.2 \\
1\end{array}$ & $\begin{array}{l}94 \\
3.8 \\
2\end{array}$ \\
\hline $\begin{array}{l}19 \\
98\end{array}$ & 453.09 & $\begin{array}{l}9094 \\
4.46\end{array}$ & $\begin{array}{l}20 \\
0.7 \\
2\end{array}$ & $\begin{array}{l}3442 \\
84.1 \\
0\end{array}$ & $\begin{array}{l}75 \\
9.8 \\
6\end{array}$ & $\begin{array}{l}4783 \\
3.65\end{array}$ & $\begin{array}{l}10 \\
5 . \\
57\end{array}$ & $\begin{array}{l}20 . \\
68\end{array}$ & $\begin{array}{l}0 \\
. \\
0 \\
5\end{array}$ & $\begin{array}{l}30 . \\
56\end{array}$ & $\begin{array}{l}0 . \\
07\end{array}$ & $\begin{array}{l}4289 \\
42.7 \\
4\end{array}$ & $\begin{array}{l}94 \\
6.7 \\
1\end{array}$ \\
\hline $\begin{array}{l}19 \\
99\end{array}$ & 475.25 & $\begin{array}{l}9596 \\
4.49\end{array}$ & $\begin{array}{l}20 \\
1.9 \\
2\end{array}$ & $\begin{array}{l}3623 \\
21.6 \\
2\end{array}$ & $\begin{array}{l}76 \\
2.3 \\
8\end{array}$ & $\begin{array}{l}5015 \\
4.30\end{array}$ & $\begin{array}{l}10 \\
5 . \\
53\end{array}$ & $\begin{array}{l}21 . \\
46\end{array}$ & $\begin{array}{l}0 \\
. \\
0 \\
5\end{array}$ & $\begin{array}{l}31 . \\
81\end{array}$ & $\begin{array}{l}0 . \\
07\end{array}$ & $\begin{array}{l}4511 \\
72.8 \\
9\end{array}$ & $\begin{array}{l}94 \\
9.3 \\
4\end{array}$ \\
\hline $\begin{array}{l}20 \\
00\end{array}$ & 497.41 & $\begin{array}{l}1009 \\
84.5 \\
3\end{array}$ & $\begin{array}{l}20 \\
3.0 \\
2\end{array}$ & $\begin{array}{l}3803 \\
59.1 \\
4\end{array}$ & $\begin{array}{l}76 \\
4.6 \\
8\end{array}$ & $\begin{array}{l}5247 \\
4.95\end{array}$ & $\begin{array}{l}10 \\
5 . \\
50\end{array}$ & $\begin{array}{l}22 . \\
24\end{array}$ & $\begin{array}{l}0 \\
0 \\
0 \\
4\end{array}$ & $\begin{array}{l}33 . \\
07\end{array}$ & $\begin{array}{l}0 . \\
07\end{array}$ & $\begin{array}{l}4734 \\
03.0 \\
4\end{array}$ & $\begin{array}{l}95 \\
1.7 \\
4\end{array}$ \\
\hline $\begin{array}{l}20 \\
01\end{array}$ & 519.58 & $\begin{array}{l}1060 \\
04.5 \\
6\end{array}$ & $\begin{array}{l}20 \\
4.0 \\
2\end{array}$ & $\begin{array}{l}3983 \\
96.6 \\
6\end{array}$ & $\begin{array}{l}76 \\
6.7 \\
7\end{array}$ & $\begin{array}{l}5479 \\
5.60\end{array}$ & $\begin{array}{l}10 \\
5 . \\
46\end{array}$ & $\begin{array}{l}23 . \\
01\end{array}$ & $\begin{array}{l}0 \\
0 \\
0\end{array}$ & $\begin{array}{l}34 . \\
33\end{array}$ & $\begin{array}{l}0 . \\
07\end{array}$ & $\begin{array}{l}4956 \\
33.1 \\
8\end{array}$ & $\begin{array}{l}95 \\
3.9 \\
1\end{array}$ \\
\hline $\begin{array}{l}20 \\
02\end{array}$ & 541.74 & $\begin{array}{l}1110 \\
25.0\end{array}$ & $\begin{array}{l}20 \\
4.9\end{array}$ & $\begin{array}{l}4164 \\
39.6\end{array}$ & $\begin{array}{l}76 \\
8.7\end{array}$ & $\begin{array}{l}5711 \\
6.06\end{array}$ & $\begin{array}{l}10 \\
5 .\end{array}$ & $\begin{array}{l}23 . \\
80\end{array}$ & $\begin{array}{l}0 \\
.\end{array}$ & $\begin{array}{l}35 . \\
58\end{array}$ & $\begin{array}{l}0 . \\
07\end{array}$ & $\begin{array}{l}5178 \\
64.7\end{array}$ & $\begin{array}{l}95 \\
5.9\end{array}$ \\
\hline
\end{tabular}




\begin{tabular}{|c|c|c|c|c|c|c|c|c|c|c|c|c|c|}
\hline & & 2 & 4 & 4 & 1 & & 43 & & $\begin{array}{l}0 \\
4\end{array}$ & & & 1 & 3 \\
\hline 20 & 563.90 & 1160 & 20 & 4344 & 77 & 5943 & 10 & 24. & 0 & 36. & 0. & 5400 & 95 \\
\hline \multirow[t]{2}{*}{03} & & 45.0 & 5.7 & 77.1 & 0.4 & 6.71 & 5. & 58 & . & 83 & 07 & 94.8 & 7.7 \\
\hline & & 6 & 9 & 6 & 9 & & 40 & & $\begin{array}{l}0 \\
4\end{array}$ & & & 6 & 8 \\
\hline 20 & 586.07 & 1210 & 20 & 4525 & 77 & 6175 & 10 & 25. & 0 & 38. & 0. & 5623 & 95 \\
\hline \multirow[t]{2}{*}{04} & & 65.1 & 6.5 & 14.6 & 2.1 & 7.36 & 5. & 36 & . & 08 & 06 & 25.0 & 9.4 \\
\hline & & 0 & 7 & 8 & 2 & & 38 & & $\begin{array}{l}0 \\
4\end{array}$ & & & 1 & 8 \\
\hline 20 & 608.23 & 1260 & 20 & 4705 & 77 & 6407 & 10 & 26. & 0 & 39. & 0. & 5845 & 96 \\
\hline \multirow[t]{2}{*}{05} & & 85.1 & 7.3 & 52.2 & 3.6 & 8.01 & 5. & 13 & . & 33 & 06 & 55.1 & 1.0 \\
\hline & & 3 & 0 & 0 & 4 & & 35 & & $\begin{array}{l}0 \\
4\end{array}$ & & & 7 & 8 \\
\hline 20 & 630.39 & 1311 & 20 & 4885 & 77 & 6639 & 10 & 26. & 0 & 40. & 0. & 6067 & 96 \\
\hline \multirow[t]{2}{*}{06} & & 25.4 & 8.0 & 95.1 & 5.0 & 8.48 & 5. & 92 & . & 58 & 06 & 86.7 & 2.5 \\
\hline & & 0 & 1 & 9 & 7 & & 33 & & $\begin{array}{l}0 \\
4\end{array}$ & & & 0 & 6 \\
\hline 20 & 652.56 & 1361 & 20 & 5066 & 77 & 6871 & 10 & 27. & 0 & 41. & 0. & 6290 & 96 \\
\hline \multirow[t]{2}{*}{07} & & 45.4 & 8.6 & 32.7 & 6.3 & 9.12 & 5. & 70 & . & 83 & 06 & 16.8 & 3.9 \\
\hline & & 3 & 3 & 1 & 8 & & 31 & & $\begin{array}{l}0 \\
4\end{array}$ & & & 5 & 2 \\
\hline 20 & 674.72 & 1411 & 20 & 5246 & 77 & 7103 & 10 & 28. & 0 & 43. & 0. & 6512 & 96 \\
\hline \multirow[t]{2}{*}{08} & & 65.4 & 9.2 & 70.2 & 7.6 & 9.78 & 5. & 48 & . & 09 & 06 & 46.9 & 5.2 \\
\hline & & 7 & 2 & 3 & 1 & & 29 & & $\begin{array}{l}0 \\
4\end{array}$ & & & 9 & 1 \\
\hline 20 & 696.88 & 1461 & 20 & 5427 & 77 & 7336 & 10 & 29. & 0 & 44. & 0. & 6734 & 96 \\
\hline \multirow[t]{2}{*}{09} & & 85.5 & 9.7 & 07.7 & 8.7 & 0.42 & 5. & 25 & . & 35 & 06 & 77.1 & 6.4 \\
\hline & & 0 & 7 & 5 & 7 & & 27 & & $\begin{array}{l}0 \\
4\end{array}$ & & & 3 & 2 \\
\hline 20 & 719.05 & 1512 & 21 & 5607 & 77 & 7566 & 10 & 30. & 0 & 45. & 0. & 6957 & 96 \\
\hline \multirow[t]{3}{*}{10} & & 05.9 & 0.2 & 50.7 & 9.8 & 5.73 & 5. & 04 & . & 58 & 06 & 50.5 & 7.6 \\
\hline & & 6 & 9 & 6 & 5 & & 23 & & 0 & & & 6 & 0 \\
\hline & & & & & & & & & 4 & & & & \\
\hline
\end{tabular}

Note: See the methodology for details about variable specifications.

Furthermore, real GFCF is predicted to decline by 0.59 percent over the forecast period; that is, the nominal rise from \#36230.77million to \#75656.73million between 1993 and 2010 notwithstanding. Although, NDR is predicted to increase from 16.77percent in 1993 to 30.04percent in 2010, this will represent a 20percent decline in real terms during the forecast period. Similarly, NLR is expected to increase from 24.31percent in 1993 to 45.58percent in 2010. However, this will amount to a 14.29percent decline in the real lending rates over the forecast period. Finally, based on forecasts, real GDP in Nigeria is expected to rise by 4.2percent (i.e. nominal terms from \#317789.23million to \#695750.56million) between 1993 and 2010 (Table 6).

\section{CONCLUSION}

\section{Key Findings and their Implications for Economic Development}

The low or negative interest rates prevailing in Nigeria can hardly be expected to enhance efficient savings mobilisation or encourage the channelling of idle funds into 
profitable investments. On the contrary, such interest rates are likely to discourage savings as well as retard investment drive in Nigeria. The high nominal interest elasticity of savings tend to suggest some scope for increasing savings deposit rates so as to attain a higher savings level in Nigeria. As such, well-designed savings mobilisation programmes such as the Rural Banking Scheme and the Community Banks appear to have ample scope for becoming successful especially in stimulating voluntary savings domestically.

The observed insensitivity of total savings to the real interest rate $(-0.10)$ tends to suggest three things. One, fiscal stabilisation (or any policy shock) that lowers the real interest rate would not automatically reduce total savings. Two, financial reform that raises the real interest rate would not automatically improve total savings. And three, tax incentives directed at enhancing personal incomes, and hence savings, would be ineffective in raising total savings (Schmidt-Hebbel et al., 1996).

Empirical analysis carried out in the study revealed that aggregate investment was negatively interest inelastic. The estimated nominal interest elasticity of investment in Nigeria over the chosen review period was -0.87 , thus implying that any increase in the interest rates on lending has the potential of discouraging domestic investment. Hence, the need exist for the monetary authorities to evolve interest rates structure that will boost savings without discouraging or lowering aggregate investment in Nigeria. This is more so since a high, positive and significant association was observed between savings and investment ratios in Nigeria for the period examined.

Although, the nation's economy was neither wholly open nor closed during the period examined, the results in this study suggested a high capital mobility in Nigeria. The implication of this finding is that domestic investment in Nigeria during the chosen review period was not financed entirely with national savings.

Ex ante forecasts have further suggested, inter alia, that a phenomenal drop in RLR between 1993 and 2010 will not translate automatically into a higher domestic investment during the same period. Similarly, a substantial decline in RDR will not prevent a sizeable growth in total savings over the forecast period. All things being equal, GDP can be expected to posit a 4.2percent growth rate, in real terms, between 1993 and 2010.

\section{REFERENCES}

CBN (Central Bank of Nigeria) 1992, Statistical Bulletin, 3(2), Dec. CBN (various issues), Economic and Financial Review. Lagos, Nigeria: Central Bank of Nigeria

Dooley,, M. P., J. A. Frankel and D. J. Mathieson, (1987), International Capital Mobility: What Do Saving-investment Correlations Tell Us? IMF Staff Papers 34 (2): 503-530.

Feldstein, M. and C. Horioka, (1980), Domestic Saving and Inter-temporal Capital Flows, Economic Journal 90:314-329.

Murphy, R., (1984), Capital Mobility and the Relationship Between Saving and Investment in OECD Countries, J. of Int'l Money and Finance 3(Dec.): 327-343.

Olubanjo, O.O.,( 2001), An Analysis of Farm-Households' Savings and Investment Patterns in Ogun State, Nigeria. An Unpublished Ph.D. Thesis. Department of Agricultural Economics, University of Ibadan, Ibadan, Nigeria.

Pindyck, R.S. and Rubinfeld, D.L., (1981), Econometrics Models and Economic Forecasts. McGraw-Hill, Inc.

Schmidt-Hebbel, K., Serven, L. and Solomon, A., (1996), Saving and Investment: Paradigms, Puzzles, Policies. The World Bank Research Observer 11 (1): 87-117. 